\title{
Mercury removal from aqueous solution and flue gas by adsorption on activated carbon fibres
}

Joa o Valente Nabais a, *, P.J.M. Carrott a, M.M.L. Ribeiro Carrott a, Marisa

Belchior a, Dulce Boavida b, Tatiana Diall b, Ibrahim Gulyurtlu b

a Centro de Química de E' vora e Departamento de Química, Universidade de E'vora,

Rua Romão Ramalho, 59, 7000-671 E'vora, Portugal

b INETI, Estrada do Pac, o do Lumiar, 22, edif. J, 1649-038 Lisboa, Portugal

Available online 15 December 2005

Abstract

The use of two activated carbon fibres, one laboratorial sample prepared from a commercial acrylic textile fibre and one commercial sample of

Kynol1, as prepared/received and modified by reaction with powdered sulfur and $\mathrm{H}_{2} \mathrm{~S}$ gas in order to increase the sulfur content were studied for

the removal of mercury from aqueous solution and from flue gases from a fluidized bed combustor. The sulfur introduced ranged from 1 to $6 \mathrm{wt} . \%$

depending on the method used. The most important parameter for the mercury uptake is the type of sulfur introduced rather than the total amount

and it was found that the $\mathrm{H}_{2} \mathrm{~S}$ treatment of ACF leads to samples with the highest mercury uptake, despite the lower sulfur amount introduced. The

modified samples by both methods can remove $\mathrm{HgCl}_{2}$ from aqueous solutions at $\mathrm{pH} 6$ within the range 290$710 \mathrm{mg} / \mathrm{g}$ (ACF) which can be

favourably compared with other studies already published. The use of a filter made with an activated carbon fibre modified by powdered sulfur

totally removed the mercury species present in the flue gases produced by combustion of fossil fuel.

\# 2005 Elsevier B.V. All rights reserved.

PACS: 81.05.Rm; 81.05.zx; 82.80.Gk; 89.60.Ec

Keywords: Activated carbon fibres; Mercury adsorption; Sulfur impregnation; Surface chemistry 